\title{
ANALIZA PROBLEMÓW W SYSTEME ZARZĄDZANIA PRODUKCJĄ W WYBRANYM PRZEDSIĘBIORSTWIE
}

\begin{abstract}
Streszczenie: W artykule przedstawiono wyniki $\mathrm{z}$ zakresu analizy problemów związanych $\mathrm{z}$ funkcjonowaniem systemu zarządzania produkcją w przedsiębiorstwie produkującym soki i napoje. Stwierdzono następujące trzy główne kwestie problemowe w badanym systemie zarządzania produkcją: 1. Ograniczona pojemność magazynu, 2. Niski stopień wykorzystania maszyn i urządzeń, 3. Długie czasy przestojów linii produkcyjnych. Wykorzystano klasyczne narzędzie jakości w postaci diagramu Ishikawy oraz technikę pytań 5WHY w celu dokonania analiz przyczynowo-skutkowych, identyfikacji przyczyn źródłowych zidentyfikowanych problemów oraz jedno $\mathrm{z}$ nowych narzędzi jakości, tj. diagram systematyki, do zaproponowania konkretnych działań i zadań, które posłużą w efekcie udoskonaleniu systemu zarządzania produkcją w przedsiębiorstwie.
\end{abstract}

Słowa kluczowe: analiza problemów, analiza przyczynowo-skutkowa, narzędzia jakości, doskonalenie

\section{Wprowadzenie}

Jak mawiał Charles Kettering, amerykański wynalazca: „problem dobrze ujęty to problem w połowie rozwiązany" [1]. Dobre zdefiniowanie problemu daje szansę na jego skuteczne rozwiązanie, ponieważ pozwala lepiej ukierunkować działania doskonalące. „Przygodę” z rozwiązywaniem problemów należy więc zacząc od dokładnego określenia obecnego problemu. We wstępnym zdefiniowaniu problemu warto uzyskać odpowiedź na trzy podstawowe pytania: gdzie tkwi problem (1), od kiedy on występuje (2), na jaką skalę jest to problem (3) [2]. Niepoprawne zdefiniowanie problemu może spowodować, że każdy z członków zespołu zrozumie sytuację inaczej a tym samym będzie próbował rozwiązać inny problem [3]. W celu właściwego zdefiniowania problemu można wykorzystać metodę 5W2H, która pozwoli na szczegółowe rozpoznanie problemu, z różnych punktów widzenia (określonych przez kryteria 5W i 2H) [4], wg zasady „lepiej mądrze stać, niż głupio biegać" [5] lub skorzystać z mapy myśli [6]. Skuteczne rozwiązanie problemu wymaga dotarcia do przyczyny źródłowej (fundamentalnej). Żeby ją znaleźć można zastosować metodę $5 \mathrm{x}$ dlaczego, gdzie zadanie 5 pytań dlaczego daje duże szanse na jej odkrycie. Nie jest to wcale zadanie takie proste. Można tutaj popełnić wiele błędów. Istnieje wiele narzędzi wspomagających analizę przyczyn problemu, do których należy zaliczyć: burzę mózgów, histogramy, analizę wykresów kontrolnych, diagram Ishikawy, analizę Pareto, analizę danych historycznych dot. problemu, mapowanie procesów, analizę FMEA [7; 8]. Identyfikacji przyczyn problemów można także dokonać metodami bardziej zaawansowanymi, statystycznymi, np. metodą

1 Dr inż., Politechnika Częstochowska, Wydział Zarządzania, Katedra Inżynierii Produkcji i Bezpieczeństwa, kryzsztof.knop@wz.pcz.pl 
planowania eksperymentów (DoE). W zależności od stopnia skomplikowania problemów można zastosować mniej lub bardziej zaawansowane narzędzia i metody ich analizy, bazujące na popularnym cyklu rozwiązywania problemów, tj. cyklu PDCA (np. arkusze Quick Kaizen, Advanced Kaizen), cyklu six sigmowym DMAIC, lub też skorzystać z różnych podejść i zagadnień do ich analizy (raporty A3, G8D, QRQC). Efektem podjętych działań powinno być zidentyfikowanie przyczyny (lub przyczyn) źródłowej problemu, w odniesieniu do której powinno podjąć się właściwe działania korygujące, czyli działania mające na celu wyeliminowanie tej przyczyny (raz na zawsze) [9]. Aby uskutecznić wprowadzenie działań korygujących i „rozbić” te działania na serię mniejszych kroków (działań) można skorzystać z różnych narzędzi wspomagających taką analizę, przykładowo z potencjału nowych narzędzi zarządzania jakością, np. z diagramu systematyki [10].

Prezentowany artykuł to case-study $\mathrm{z}$ analizy problemów związanych $\mathrm{z}$ funkcjonowaniem systemu zarządzania produkcją $\mathrm{W}$ przedsiębiorstwie produkującym soki i napoje w oparciu o różne narzędzia i metody wspomagające taką analizę. Artykuł potwierdza skuteczność podejść do analizy problemów z wykorzystaniem takich narzędzi i metod, jak: diagram Ishikawy, metoda 5WHY, diagram systematyki. Obiektem badanym jest przedsiębiorstwo zajmujące się produkcją napojów i soków.

\section{Wyniki badań}

\subsection{Identyfikacja problemów}

W celu identyfikacji problemów w systemie zarządzania produkcją badanego przedsiębiorstwa wykorzystano informacje $\mathrm{z}$ przeprowadzonej oceny wielokryterialnej, wskaźnikowej dla systemu, bazującej głównie na wskaźnikach produktywności (ale nie tylko). W ramach badań nad system zarządzania produkcją obliczono następujące wskaźniki, w celu jego oceny: produktywność pracy, produktywność surowców, wskaźnik jakości, wskaźniki stopnia wykorzystania urządzeń, czasu przestojów, kosztu utrzymania zapasów, wskaźnik realizacji planów produkcji. Za pomocą tych wskaźników dokonano kompleksowej oceny systemu zarządzania produkcją badanej firmy (do tego celu wykorzystano wskaźnik oceny syntetycznej). Wyniki analizy i oceny systemu zarządzania produkcją posłużyły do wskazania jego słabych stron, inaczej: pozwolił zidentyfikować problemy w systemie zarządzania produkcją, którymi należy się zająć. Stwierdzono następujące trzy zasadnicze problemy: ograniczona pojemność magazynu, niski stopień wykorzystania maszyn i urządzeń, długie czasy przestojów linii produkcyjnych, które postanowiono przeanalizować oraz rozwiązać. W tym celu powołano grupę złożoną z przedstawicieli 
obszarów, których problemy bezpośrednio dotyczą. Wykorzystano potencjał pracy zespołowej w celu analizy i poszukiwań rozwiązań badanych problemów.

\subsection{Analiza problemów za pomocą diagramu Ishikawy i metody 5 x dlaczego}

Dla analizy problemów zidentyfikowanych w badanym systemie zarządzania produkcją zastosowano jedno z narzędzi doskonalenia jakości (z grupy tzw. „starych”, tradycyjnych), tj. diagram Ishikawy [11] oraz technikę pytań 5 x dlaczego [12].

Celem wykorzystania diagramu Ishikawy było dogłębne rozpoznanie przyczyn badanych problemów oraz określenie relacji pomiędzy przyczynami a skutkiem [13; 14] (tj. badanymi problemami), z kolei celem zastosowania metody $5 \mathrm{x}$ dlaczego było wykrycie fundamentalnej (źródłowej) przyczyny badanych problemów [15], w następstwie zaproponowanie środków zaradczych, co w efekcie miało przyczynić się do skutecznego rozwiązania tych problemów.

Wynik wykorzystania diagramu Ishikawy do identyfikacji przyczyn pierwszego badanego problemu - ograniczona pojemność magazynu, przedstawia rysunek 1. Skupiono się na czterech podstawowych kategoriach przyczyn - człowiek, metoda, maszyna i zarządzanie. W wyniku analizy przyczyn problemu oraz ich wpływu stwierdzono, że problem związany jest przede wszystkim z kategorią „maszyna”. Postanowiono przeanalizować badany problem z punktu widzenia tej kategorii wykorzystując $\mathrm{w}$ tym celu metodę $5 \mathrm{x}$ dlaczego. Dzięki temu odkryto przyczynę źródłową tego problemu.

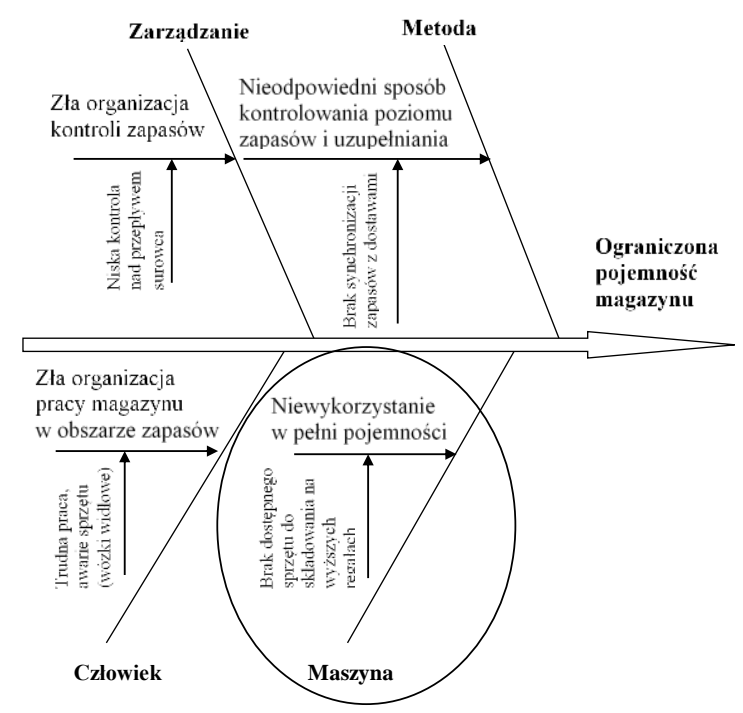

Rys. 1. Diagram Ishikawy dla analizy przyczyn problemu $\mathrm{nr} 1$ ograniczona pojemność magazynu Źródto: Opracowanie własne 
Wynik wykorzystania metody $5 \mathrm{x}$ dlaczego do identyfikacji przyczyny źródłowej problemu nr 1 - ograniczona pojemność magazynu przedstawiono w tablicy 1.

Tab. 1. Metoda 5 x dlaczego do identyfikacji przyczyny źródtowej problemu nr 1 ograniczona pojemność magazynu

\begin{tabular}{|c|c|}
\hline PROBLEM 1: & Ograniczona pojemność magazynu. \\
\hline Pytanie 1. & Dlaczego magazyn ma ograniczoną pojemność? \\
\hline Odpowiedź: & Nie jest wykorzystywana w petni jego pojemność. \\
\hline Pytanie 2. & Dlaczego nie jest wykorzystywana w pełni pojemność magazynu? \\
\hline Odpowiedź: & Brak dostępnego sprzętu do sktadowania na wyżsych regałach. \\
\hline Pytanie 3. & $\begin{array}{l}\text { Dlaczego brak jest dostępnego sprzętu do składowania na wyższych } \\
\text { regałach? }\end{array}$ \\
\hline Odpowiedź: & $\begin{array}{l}\text { Wózki widłowe służace do rozmieszczania towaru na wyższych regałach } \\
\text { często ulegają uszkodzeniu. }\end{array}$ \\
\hline Pytanie 4. & $\begin{array}{l}\text { Dlaczego wózki widłowe służące do rozmieszczania towaru na wyższych } \\
\text { regałach często ulegają uszkodzeniu. }\end{array}$ \\
\hline Odpowiedź: & Wózki widłowe nie sq regularnie serwisowane. \\
\hline Pytanie 5. & Dlaczego wózki widłowe nie są regularnie serwisowane? \\
\hline Odpowiedź: & $\begin{array}{l}\text { Brak opracowanego terminarza prac serwisowych dla wózków widtowych, } \\
\text { w którym określona byłaby częstotliwość przeglądów ich stanu technicznego. }\end{array}$ \\
\hline Przyczyna źródłowa: & $\begin{array}{l}\text { Brak opracowanego terminarza prac serwisowych uwzględniającego } \\
\text { przegląd wózków widłowych powodowal, że działania służb utrzymania } \\
\text { ruchu ograniczały się jedynie do „gaszenia pożarów", tj. napraw tego } \\
\text { sprzętu po wystąpieniu awarii. Częste awarie wózków powodowały } \\
\text { z kolei brak możliwości ich wykorzystania. }\end{array}$ \\
\hline Środek zaradczy: & $\begin{array}{l}\text { Należy wprowadzić kwartalny serwis wózków widłowych i ująć tą } \\
\text { czynność w terminarzu prac serwisowych. Kwartalny serwis wózków } \\
\text { widlowych powinien być wystarczający dla zapewnienia ich } \\
\text { bezawaryjnej pracy. Można także zakupić dodatkowy wózek widlowy, } \\
\text { który bylby wózkiem zastępczym, wykorzystywanym w przypadku } \\
\text { możliwej awarii jednego z wózków. }\end{array}$ \\
\hline
\end{tabular}

Źródło: Opracowanie własne

Wynik wykorzystania diagramu Ishikawy do identyfikacji przyczyn drugiego badanego problemu - niski stopień wykorzystania maszyn i urządzeń, przedstawia rysunek 2. Skorzystano z zestawu tych samych kategorii przyczyn w odniesieniu do badanego problemu. W wyniku analizy wpływu przyczyn na badany problem stwierdzono, że jest on związany głównie z kategorią „maszyna”. 


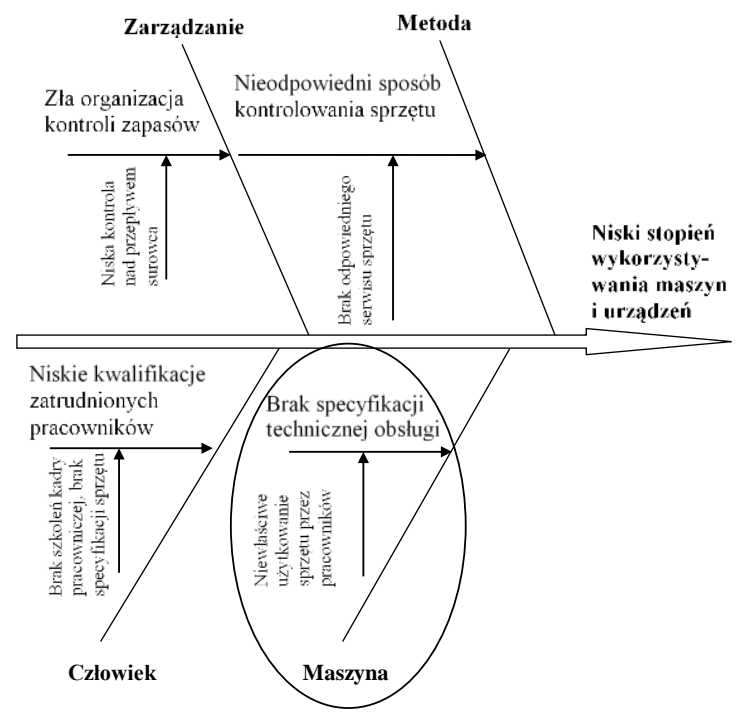

Rys. 2. Diagram Ishikawy dla analizy przyczyn problemu nr 1 -ograniczona pojemność magazynu

Źródto: Opracowanie własne

Wynik wykorzystania metody 5 x dlaczego do identyfikacji przyczyny źródłowej problemu nr 2 - niski stopień wykorzystania maszyn i urządzeń przedstawiono w tablicy 2 .

\section{Tab. 2. Metoda 5 x dlaczego do identyfikacji przyczyny źródtowej problemu nr 2 - niski} stopień wykorzystania maszyn i urządzeń

\begin{tabular}{|l|l|}
\hline PROBLEM 2: & Niski stopień wykorzystania maszyn i urządzeń. \\
\hline Pytanie 1. & Dlaczego jest niski stopień wykorzystania maszyn i urządzeń? \\
\hline Odpowiedź: & Pracownicy niewtaściwie wykorzystuja sprzęt. \\
\hline Pytanie 2. & Dlaczego jest niewłaściwie wykorzystywany sprzęt? \\
\hline Odpowiedź: & Pracownicy nie maja specyfikacji technicznej sprzętu. \\
\hline Pytanie 3. & Dlaczego pracownicy nie mają specyfikacji technicznej sprzętu? \\
\hline Odpowiedź: & Specyfikacja techniczna sprzętu nie została opracowana. \\
\hline Pytanie 4. & Dlaczego specyfikacja sprzętu nie została opracowana? \\
\hline Odpowiedź: & Kierownictwo nie miato takich priorytetów. \\
\hline Pytanie 5. & Dlaczego kierownictwo nie miało takich priorytetów? \\
\hline Odpowiedź: & $\begin{array}{l}\text { Nie sądzono, że brak specyfikacji technicznej ma znaczacy wplyw na stopień } \\
\text { wykorzystywania maszyn i urzadzeń. }\end{array}$ \\
\hline Przyczyna źródłowa: & Brak specyfikacji technicznej wykorzystania maszyn i urządzeń. \\
\hline Środek zaradczy: & $\begin{array}{l}\text { Należy zlecić przygotowanie specyfikacji technicznej przez } \\
\text { kierownictwo a następnie zapoznać z nią kadrę pracowniczą } \\
\text { obsługującą maszyny i urządzenia. }\end{array}$ \\
\hline
\end{tabular}

Źródto: Opracowanie własne 
Diagram Ishikawy dla identyfikacji przyczyn trzeciego badanego problemu długie czasy przestojów linii produkcyjnych przedstawia rysunek 3. Bazą do analizy były także cztery kategorie przyczyn. W wyniku analizy przyczyn badanego problemu stwierdzono, że jest on związany przede wszystkim z kategorią „metoda”.

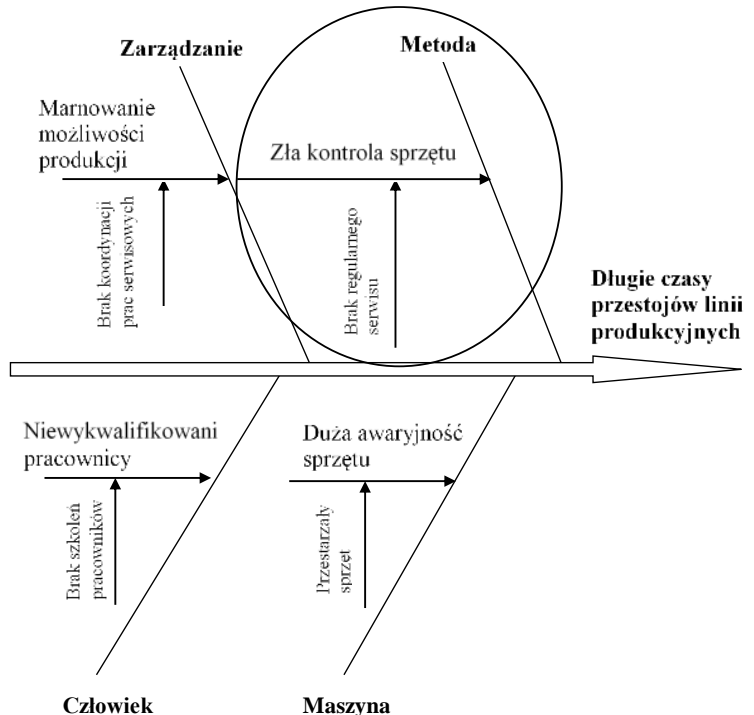

\author{
Rys. 3. Diagram Ishikawy dla \\ analizy przyczyn problemu nr 1 - \\ dlugie czasy przestojów linii \\ produkcyjnych
}

Źródto: Opracowanie własne

Przeanalizowano badany problem wykorzystując w tym celu metodę 5 x dlaczego. Dzięki temu odkryto przyczynę źródłową tego problemu. Wynik wykorzystania metody 5 x dlaczego przedstawiono w tablicy 3 .

Tab. 3. Metoda 5 x dlaczego do identyfikacji przyczyny źródlowej problemu nr 3 dlugie czasy przestojów linii produkcyjnych

\begin{tabular}{|l|l|}
\hline PROBLEM 3: & Dlugie czasy przestojów linii produkcyjnych. \\
\hline Pytanie 1. & Dlaczego są długie czasy przestojów linii produkcyjnych? \\
\hline Odpowiedź: & Wykorzystywany sprzęt cechuje duża awaryjność? \\
\hline Pytanie 2. & Dlaczego jest duża awaryjność wykorzystywanego sprzętu? \\
\hline Odpowiedź: & Sprzęt jest źle kontrolowany. \\
\hline Pytanie 3. & Dlaczego sprzęt jest źle kontrolowany? \\
\hline Odpowiedź: & Nie jest przeprowadzany regularny serwis maszyn i urzadzeń. \\
\hline Pytanie 4. & Dlaczego nie jest przeprowadzany regularny serwis maszyn i urządzeń? \\
\hline Odpowiedź: & Nie ma opracowanego terminarza cyklicznych serwisów. \\
\hline Pytanie 5. & Dlaczego nie ma opracowanego terminarza serwisów? \\
\hline Odpowiedź: & Brak kontroli nad przeprowadzanym serwisem maszyn i urzadzeń. \\
\hline Przyczyna źródłowa: & Brak kontroli nad przeprowadzanym serwisem maszyn i urządzeń. \\
\hline Środek zaradczy: & $\begin{array}{l}\text { Wprowadzenie kontroli nad serwisem oraz ujęcie jej w terminarzu } \\
\text { cyklicznego ich serwisowania. }\end{array}$ \\
\hline
\end{tabular}

Źródto: Opracowanie własne 
$\overline{\mathrm{W} \text { wyniku wykorzystania diagramu Ishikawy i metody } 5 \mathrm{x} \text { dlaczego udało się }}$ przeanalizować przyczyny zidentyfikowanych problemów oraz wskazać na ich przyczyny źródłowe, następnie zaproponować działania korygujące, które pozwoliłby daną przyczynę problemu wyeliminować. Kolejnym zadaniem, po wdrożeniu działań korygujących, będzie ocena skuteczności podjętych działań w dłuższym horyzoncie czasowym, bo tylko ona pozwoli uzyskać informację, czy działania te będą skuteczne.

\subsection{Sposoby rozwiązania problemów $w$ ujęciu diagramu systematyki}

Dla lepszego zaprezentowania przedstawionych propozycji doskonalenia badanego systemu zarządzania produkcją wykorzystano jedno z narzędzi doskonalenia jakości, z grupy narzędzi opisowych („nowych”), tj. diagram systematyki. Diagram systematyki posłużył do graficznej analizy czynności niezbędnych do osiągnięcia trzech wytyczonych celów, jeśli chodzi o doskonalenie, tj.: 1. Zwiększenie powierzchni magazynowej, 2. Zwiększanie stopnia wykorzystania maszyn i urządzeń, 3. Zmniejszenie liczby przestojów linii produkcyjnych.

Wynik wykorzystania diagramu systematyki do przedstawienia działań niezbędnych do zwiększenia powierzchni magazynowej przedstawia rys. 4 .

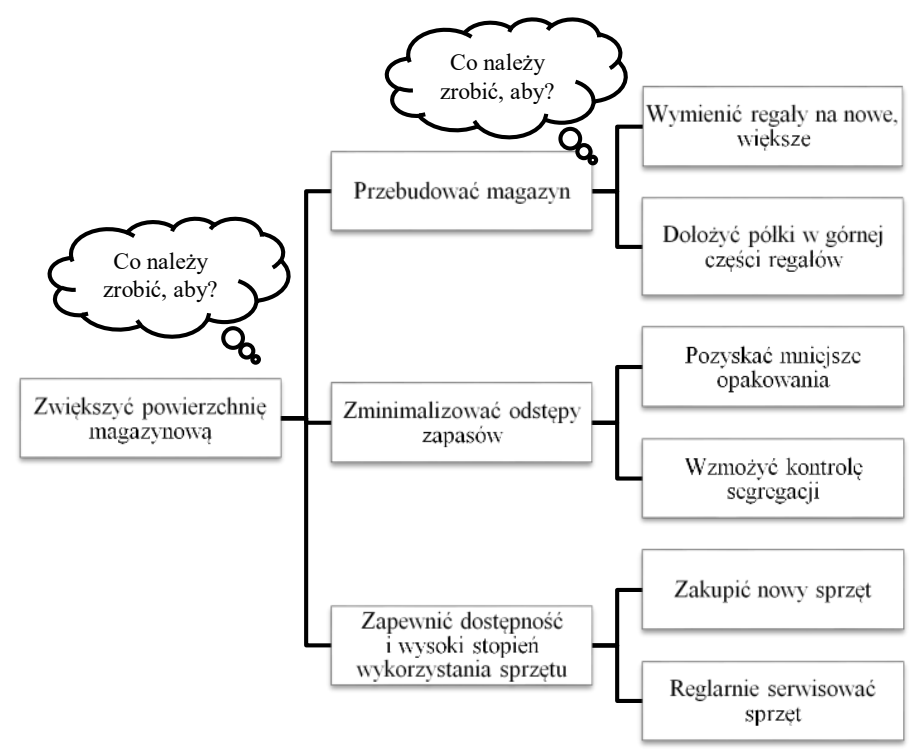

Rys. 4. Diagram systematyki dla przedstawienia dzialań podjętych $w$ celu osiagnięcia celu zwiększenie pojemności magazynu

Źródto: Opracowanie własne 
Wykorzystanie diagramu systematyki do prezentacji działań niezbędnych do zwiększania stopnia wykorzystania maszyn i urządzeń przedstawia rys. 5.

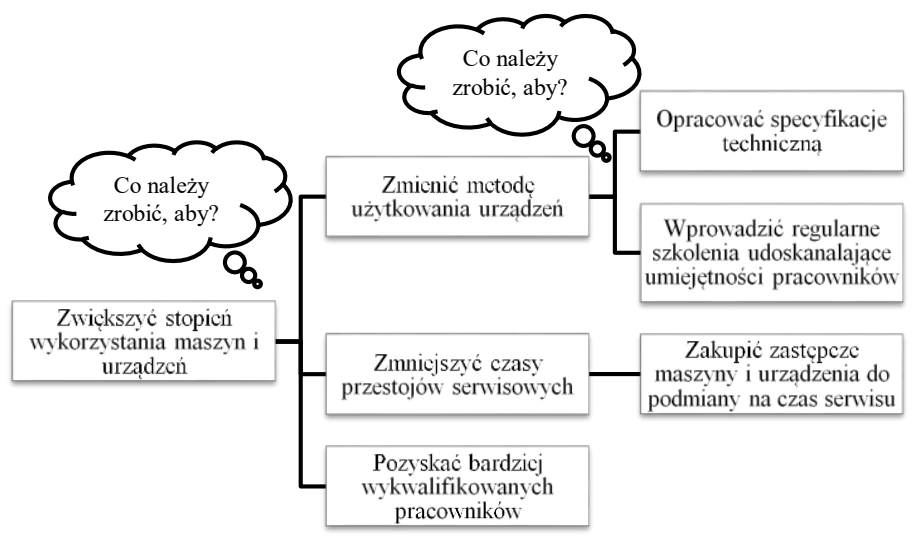

Rys. 5. Diagram systematyki dla przedstawienia dzialań podjętych $w$ celu osiagnięcia celu zwiększanie stopnia wykorzystania maszyn i urzadzeń

Źródto: Opracowanie własne

Diagram systematyki do ujęcia działań koniecznych do zmniejszenia liczby przestojów linii produkcyjnych przedstawia rys. 6 .

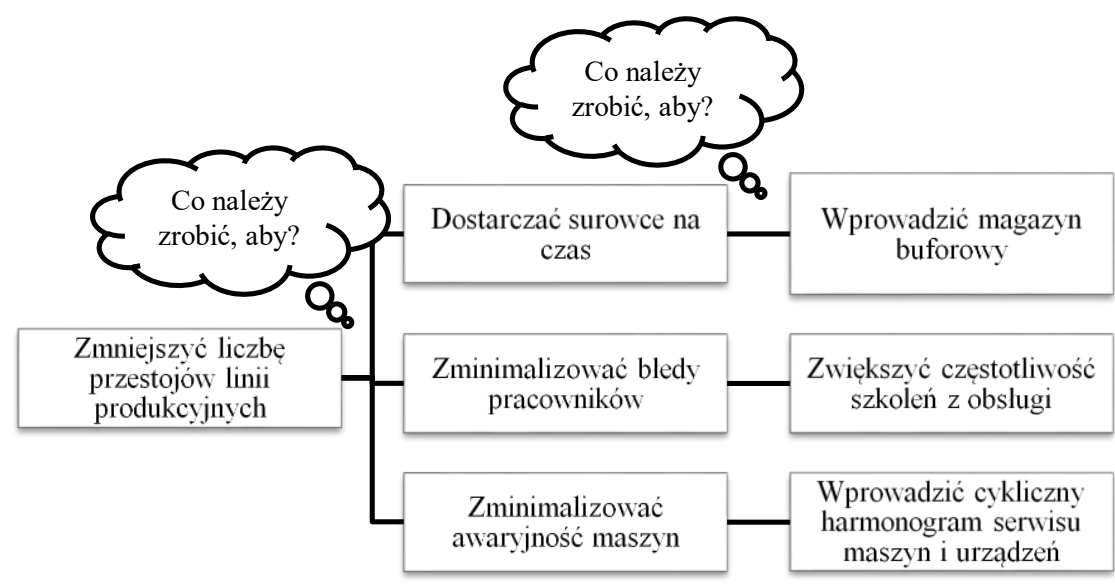

Rys. 6. Diagram systematyki dla przedstawienia dzialań podjętych w celu osiagnięcia celu zmniejszenie liczby przestojów linii produkcyjnych

Źródto: Opracowanie własne 
Diagram systematyki pozwolił usystematyzować działania niezbędne do osiągnięcia celów związanych z doskonaleniem; pozwolił przejść „od ogółu do szczegółu”, od ogólnych celów do konkretnych działań, jakie należy podjąć.

\section{Podsumowanie}

$\mathrm{W}$ artykule wykazano słabości $\mathrm{w}$ istniejącym systemie zarządzania produkcją w badanym przedsiębiorstwie produkcyjnym soki i napoje, które dokładniej uwidoczniono po zastosowaniu diagramu Ishikawy oraz metody $5 \mathrm{x}$ dlaczego. Zwrócono uwagę na takie jakościowe aspekty wpływające na system zarządzania produkcją, jak: kontrola serwisu urządzen, harmonogram ich przeprowadzania, brak dostępności specyfikacji technicznych maszyn i urządzeń dla pracowników. Wykazano także, że należy poprawić stopień wykorzystania urządzeń, zmniejszyć liczbę godzin przestojów linii produkcyjnej.

Za pomocą pogłębionej analizy zidentyfikowanych problemów w oparciu o diagram Ishikawy wykazano, że problemem w firmie jest mała powierzchnia magazynowa, która powinna zostać powiększona poprzez przebudowę, w taki sposób, aby można zwiększyć wielkość surowca niezbędnego do produkcji. Zaproponowano także, aby nowe pomieszczenia magazynowe odpowiednio wyposażyć w dodatkowy sprzęt w postaci wózka widłowego i zatrudnić dodatkowo osobę, która będzie się zajmowała bieżącą kontrolą stanu zapasów i ich kondycją. Aby zwiększyć stopień wykorzystania maszyn i urządzeń, zaproponowano jako przeciwdziałanie, zwiększenie kontroli serwisowej oraz podniesienie kwalifikacji pracowników poprzez wdrożenie dodatkowych szkoleń. W celu wyeliminowania przestojów linii produkcyjnej ponad czas niezbędny do remontów i przeglądów, zaproponowano pozyskiwanie opakowań $\mathrm{z}$ różnych źródeł (opakowania zwrotne, producent) i realizację ich dostaw w trybie „just in time”. Zaproponowano także zgromadzenie niewielkich zapasów opakowań oraz zwiększenie powierzchni magazynowej na ich przechowywanie.

Identyfikacja, analiza i rozwiązywanie problemów jest sztuką i wymaga od zespołu zajmującego się takim tematem odpowiedniej wiedzy i doświadczenia oraz korzystania $\mathrm{z}$ właściwych metod i narzędzi, które niewątpliwie taką analizę wspomagają. Dużo zależy od stopnia skomplikowania problemu i wiedzy na jego temat członków zespołu. Na każdym $\mathrm{z}$ tych etapów w drodze do rozwiązania problemu można popełnić błędy, przez co problem może nie zostać rozwiązany, lub będzie rozwiązany, ale nieskutecznie (pojawi się ponownie). Prawdziwą sztuką jest rozwiązanie danego, rozpatrywanego problemu raz na zawsze oraz najlepiej dobrze za pierwszym razem. Studium przypadku przedstawione w artykule to przykład, w jaki sposób, za pomocą prostych narzędzi i metod można „zająć się” skutecznie danym problemem. Potencjał ukryty w narzędziach i metodach do rozwiązywania problemów jest duży, przy czym należy właściwie z nich korzystać, aby osiągnąć cel - 
rozwiązanie problemu. Same stosowanie narzędzi i metod nie powinno być celem samym w sobie, ale jedynie środkiem do osiągnięcia celu - rozwiązania problemu raz na zawsze. Wysiłek podjęty w kierunki rozwiązania problemu na pewno nie jest czasem straconym, bo każdy problem to szansa na doskonalenie, z kolei każdy problem dobrze rozwiązany to wykonany kolejny krok w drodze do doskonałości.

\section{Bibliografia}

[1] https://pl.wikiquote.org/wiki/Charles_Kettering

[2] P. Tymcio. Optymalizacja procesu produkcji - trudna, ale opłacalna sztuka, 2018. Pobrane z: https://blog.human40.eu/2018/05/22/optymalizacja-procesu-produkcjitrudna-ale-oplacalna-sztuka/ (dostęp: 22.05.2018).

[3] J. Kruszewska. Jaki jest pierwszy krok analizy problemów?, 2017. Pobrane z: https://tqmsoft.com/pl/qnowhow/2017-03-08/jaki-jest-pierwszy-krok-analizyproblemow (dostęp: 08.03.2018).

[4] M. Ingaldi, K. Nowakowska. Wykorzystanie metody $5 \mathrm{~W} 2 \mathrm{H}$ do doskonalenia produkcji wentylatorów. Archiwum Wiedzy Inżynierskiej, Tom 1, nr 1 (2016), s. 39-41.

[5] A. Mydlarz. 5W2H - lepiej madrze stać, niż glupio biegać - perspektywa problemu, 2017. Pobrane z: http://inzynierjakosci.pl/2017/12/5w2h-przyklad-opis-metody/ (dostęp: 10.06.2018).

[6] Ch. Griffiths, T. Buzan. Mapy myśli dla biznesu. Gliwice: Helion, 2016.

[7] A. Hamrol. Zarzadzanie jakościa z przykładami. Warszawa: PWN, 2006.

[8] B. Czyżewski, J. Potęga. Narzędzia analizy i doskonalenia jakości. Poznań: Wielkopolski Klub Jakości FSNT NOT, 2007.

[9] M. Ingladi. Analysis of the Quality Problems During Production Process of the Stud Frame of the Stretching Station. Production Engineering Archives, Vol. 2, nr 1, 2014, pp. $2-5$.

[10]T. Corejowa, S. Borkowski. Instrumenty rozwiqzywania problemów w zarzadzaniu. Sosnowiec: WSZiMS - Wydawnictwo Wyższej Szkoły Zarządzania i Marketingu w Sosnowcu, 2004.

[11]S. Borkowski. Mierzenie poziomu jakości. Sosnowiec: Humanitas, 2005.

[12]A. Lis, Kowal K., M. Brożyńska, M. Szymczak. 5 x dlaczego. Pierwszy podręcznik metody. 2K Consulting, 2014.

[13]J. Rosak-Szyrocka. Production process quality and its improvement. Zeszyty Naukowe Quality. Production. Improvement, No 1(6) 2017, s. 202-212.

[14]M. Jagusiak-Kocik, K. Knop. Wykorzystanie wybranych narzędzi zarzqdzania jakościa

i metody FMEA w przedsiębiorstwie produkujacym konstrukcje spawane dla maszyn. Zeszyty Naukowe Quality. Production. Improvement. Nr 1(4), 2016, s. 54-65. 
[15]M. Makowska, A. Kaczmarek, R. Budzik. "Application the 5XWhy? Method in Identification the Reasons of Discrepancies in Pistons for Combustion Engine Production", in Kvalita a Spol'ahlivost Technickych Systemov. 14 Medzinarodna Vedecka Konferencia. Nitra, 2009, pp. 92-95.

\title{
ANALYSIS OF PROBLEMS IN A PRODUCTION MANAGEMENT SYSTEM IN A SELECTED ENTERPRISE
}

\begin{abstract}
The article presents the results of the analysis of problems related to the functioning of the production management system in the juice and beverage production company. The following three main problems were found in the production management system examined: 1. Limited storage capacity, 2. Low utilization of machinery and equipment, 3. Long downtimes of production lines. A classic quality tool in the form of the Ishikawa diagram and the technique of 5WHY question were used to perform cause-and-effect analyzes, identify the root causes of the identified problems, it was also used a new quality tool, i.e. the tree diagram, to propose specific actions and tasks that will serve as a result of improving the company's production management system.
\end{abstract}

Key words: problem analysis, cause and effect analysis, quality tools, improvement.

Data przestania publikacji do Redakcji: 20.06 .2018

Data akceptacji publikacji przez Redakcję: 25.07.2018 